\title{
Several Views on the Reform of Supervision System in the Context of Anti-corruption in China
}

\author{
Yi Zou \\ School of Arts and Law \\ Wuhan University of Technology \\ Wuhan, China 430070
}

\begin{abstract}
With the continuous promotion of anticorruption work in China, the loopholes in the current supervision system are increasingly obvious. Aiming to thoroughly change the situation that the legal status in the past is not independent, anti-corruption powers are scattered and the efficiency is low. The reform of the state supervisory system has complied with the new requirements of anticorruption in the new era and proposed the establishment of a centralized supervisory Committee with powers parallel to the government status. By analyzing the existing problems in the supervision system, this paper expounds the urgency and necessity of the reform of the supervision system, analyzes the problems that will be met in the reform and puts forward feasible solutions.
\end{abstract}

Keywords-power to supervise; the building of a clean and honest government in the national supervision system first; the current situation of China's supervision system

\section{INTRODUCTION}

\section{A. China's Current Anti-corruption Supervision and Leadership System and Working Mechanism}

Compared with the western Ombudsman system, by resolving complaints to provide relief and resolving administrative disputes, the overall framework of China's anti-corruption supervision and leadership system and working mechanism is the unified leadership of party committees, the joint management of party and government, the organization and coordination of commission for discipline inspection, the responsibilities of departments, and the support and participation of the masses. In practical work, the main functional institutions responsible for anticorruption and anti-corruption construction are discipline inspection organs of the communist party of China, state judicial organs, administrative supervision organs, state corruption prevention bureau and auditing organs. In addition to these main institutions, public security, finance and other relevant departments and institutions also undertake anti-corruption related work according to law within the scope of their own responsibilities.

\section{B. The Existing Problems of the Current Supervision System}

China's anti-corruption supervision system has made great achievements in preventing and combating job-related crimes in the past. However, in the process of the practice and operation of the system, there are still many problems that need to be solved. There are mainly the following points:

Many anti-corruption monitoring institutions and scattered forces have caused the waste of human, material and financial resources. China's strength to crack down on duty crime is scattered among various institutions of different nature, such as the party's organs, judicial organs and administrative organs. As a result of various institutions and mutual independence among them, the time cost of communication in anti-corruption work has increased and the efficiency has decreased. It is also difficult to concentrate people, money and things on investigating major difficult cases, which leads to waste of resources, and it is easy to miss the best opportunity to solve crimes, so that corrup officials who violate discipline and law can go unpunished.

The powers and responsibilities of anti-corruption supervision institutions cross, the boundaries are unclear, and there is a lack of standardized and efficient cohesion and cooperation. Because of the lack of relevant specific provisions on division of labor and cooperation among various supervisory functional institutions, it is inevitable that various departments will overlap, lack of supervision and buck-passing each other when performing their duties, which greatly affects the effective implementation of the overall function of the supervisory system. For example, discipline inspection and supervision organs attach great importance to cracking down on the economic illegal and criminal activities of government officials, such as bribery, etc., and sometimes some measures taken will exceed their own authority, acting as part of the functions and powers of the procuratorial organ anti-corruption bureau.

The legal status is not independent, and the supervision work cannot be really implemented. The current administrative supervision system implements double leadership, that is, the state supervision department is under the leadership of the state Council, and local supervisory organs at all levels are under the leadership of both the people's government where they are located and the 
supervisory organs at higher levels. In fact, as the supervisory organs at all levels hold the personnel and financial rights in the hands of local governments, relevant cases have to be submitted to the government for examination and approval. Making the supervisory organ lose the basis of independent exercise of its functions and powers, the development of its business is limited, and the role and strength of its supervisory task are greatly influenced. Leading to the failure of the discovery mechanism, the failure of the prevention mechanism and the weakness of the punishment mechanism of corruption, and the supervision at the same level are useless.

There is blind spot in supervision. At present, the investigation object of the disciplinary Committee is limited to party members and comrades in the party. For a long time, in accordance with the provisions of the administrative supervision law, the supervision object of the administrative supervision department is the government and its government appointed staff, and it is difficult to cover other state organs such as legislative organs, judicial organs and public servants, managers of state-owned collective enterprises, etc.

There is no direct supervisory relationship between the NPC and the current supervisory organs. Because the supervision of the national people's congress on the government is mainly the supervision of the abstract administrative acts of the government, including the administrative legislation, and the supervision of the specific administrative acts of the government is more than enough. In addition, the relationship between the people's congress and the discipline inspection Committee, the administrative supervisory organ or the anti-corruption bureau of the procuratorate is indirect, which makes the people's congress lack direct supervision over the behavior of the supervisory organ.

\section{THE PROSPECT ANALYSIS OF THE REFORM OF NATIONAL SUPERVISION SYSTEM}

The reform of the state supervision system is a major political reform and a major judicial reform related to the overall situation. The reform of the state supervisory system will explore the construction of a more efficient state supervisory organ, bringing all public officials into the scope of supervision, truly realizing full coverage and no dead corners, and playing a greater role in building a clean government, protecting citizens' rights and promoting the construction of socialist legal system.

\section{A. The Summary of the Supervisory Committee}

The supervisory Committee is a national anti-corruption working body under the leadership of the party, which integrates the functions of investigating and punishing corruption and bribery, dereliction of duty and dereliction of duty, and preventing duty crimes of various departments of anti-corruption organs such as the supervision department (bureau) of the people's government and the corruption prevention bureau of the people's procuratorate. The supervisory Committee is the specialized organ that exercises the state supervisory function, and it will co-locate with the party's disciplinary inspection Committee.

The status of the supervisory Committee is improved The supervisory Committee is produced by the people's congress at the corresponding level, is responsible for the people's congress at the corresponding level and its standing Committee and is subject to its supervision. The supervisory Committee is also responsible for and subject to supervision by the supervisory Committee at the next higher level. The supervisory Committee will be separated from government departments and become a supervisory organ parallel to government status, which changes the institutional affiliation and greatly enhances its independence, realizing the transformation from "administrative supervision" to "supervisory administration", which is conducive to getting rid of the weak supervision mode of previous sectorization and improving the supervision effect on public officials.

The supervision scope of the supervisory Committee is expanded. The scheme puts forward: "expanding the scope of supervision, enriching the means of supervision, and realizing the comprehensive coverage of supervision of public officials exercising public power." The extension of "public officials" here is greater than that of civil servants, including managers of state-owned collective enterprises. Although the staffs in these units are not all civil servants, they all hold public power and provide public services. By incorporating them into the scope of supervision, the reform will help to achieve comprehensive coverage of public officials' supervision and put an end to blind areas and corners of supervision.

The functions and powers of the supervisory Committee are enhanced. The supervisory Committee shall, in accordance with the administrative authority, supervise all public officials exercising public power in the region according to law; Perform the duties of supervision, investigation and disposal. Supervise and inspect the performance of duties, impartiality, honesty in politics and ethics of public officials according to law; Investigating the illegal and duty-related crimes such as suspected corruption and bribery, abuse of power, dereliction of duty, rent-seeking of power, transmission of interests, corruption and waste of state assets. It is to make a decision on the disposal of the above investigation results, and to transfer the suspected duty crime to the procuratorial organ for public prosecution according to law.

\section{B. The Location of the Pilot and Its Value}

The reform of national supervision system has chosen Beijing, Shanxi and Zhejiang provinces to carry out pilot work. There are three reasons. One is that these three places have a deep anti-corruption foundation. In the past few years, outstanding achievements have been made in combating jobrelated crimes, and relevant practical work experience has been accumulated. Secondly, it is representative. Shanxi, located in the mid-west of China, with relatively backward economy, is a key anti-corruption area in recent years. Since the 18th national congress of the communist party of China, the anti-corruption work has achieved remarkable results, 
and some experience and methods worthy of reference by other provinces have been explored. Zhejiang is a province with developed economy in the southern coastal area. Private enterprises are developed and private economy develops rapidly. corruption issues such as collusion and utilization between private entrepreneurs and government officials are also more prominent. Beijing, as a municipality directly under the central government and a political center, enjoys good guarantee conditions for anti-corruption construction and system construction, and putting major political and judicial reforms in the capital will have greater political influence and stronger demonstration effect. The third is to conduct the pilot work of the supervisory Committee in these three places, each with its unique value, and will encounter different problems in different fields and aspects in the establishment, operation and practical effect of the system and mechanism, which is conducive to accumulating more experiences and lessons, and facilitating the next step to be summarized and promoted to the whole country.

\section{The Problems Will Be Involved in the Reform}

1) Amendments to the constitution and related laws and regulations: First of all, to promote the reform of the national supervision system, we must promote the revision of the constitution, because the establishment of the supervisory Committee will change the political structure of "one government, two houses". In order to adapt to the changes and development of society and give full play to its role, we need to amend the constitution, and we also need to amend the administrative supervision law, the organization law of the people's procuratorate and the organization law of the state Council. Because the reform needs to "divest" and re-integrate the original powers of supervision and supervision of the government and the power of procuratorate to investigate crimes by taking advantage of duty. Therefore, it is necessary to amend or repeal the existing rights and obligations related to the abovementioned laws by amending the law. At the same time, the "coordination and convergence between the supervisory Committee and judicial organs" put forward in the pilot scheme also requires that the criminal procedure law be amended accordingly, so as to realize the efficient cooperation between the supervisory Committee and the people's procuratorate. On this basis, we should also formulate the organic law of the supervisory Committee and the national supervisory law which are matched with the reform. Because in the constitution, although new content about the supervisory Committee is added, including its position, nature and responsibilities. But these provisions are still relatively macro and operability is not strong, and it is also necessary to legalize the functions and powers of the supervisory Committee mentioned in the scheme, and to legislate separately to make more specific provisions on the nature, responsibilities, powers, contents of supervisory work, supervisory procedures and legal responsibilities of supervisory personnel, so as to truly have legal basis. It is particularly noteworthy that under the exploratory reform, the amendment of the constitution and laws cannot be achieved at the beginning of the reform but can only be carried out when the pilot work is completed and the experience has matured, and it is quite necessary and feasible to popularize the experience throughout the country.

2) The power transfer of procuratorial organs to investigate duty crimes: Currently, according to the scheme, the supervisory Committee monitors all public officials exercising public power in this region according to the administrative authority. Perform the duties of supervision, investigation and disposal. Among them, the expression "investigation" is not used, but "investigation", which means that the supervisory Committee can't take the place of the power of investigation and so on of the procuratorate. But if we want to separate the power of procuratorate to investigate and deal with duty crimes, it will inevitably involve the transfer of investigation power of duty crimes. Duty crime abuses the public power of the state, and the occurrence of duty crime damages the credibility of the state and government. This determines that the investigation right of duty crime must be exercised by a relatively independent specialized supervision organ. If the right of investigation is not transferred, the supervisory Committee will only enjoy the right of investigation which is greatly limited, and it will not only be unable to play its role of anti-corruption and advocating honesty, but also not conducive to changing the disadvantages of procuratorial organs " being both athletes and referees".

3) Supervision of the supervisory Committee: The supervisory Committee is a state organ with high concentration of anti-corruption power, but once its power is abused, its consequences are unimaginable. As a result, it is a problem that the reform has to face and must solve to put an end to "darkness under the light".

\section{CONCLUSION}

1) The implementation of administrative supervision and vertical leadership: Change the dual leadership into a single vertical leadership, that is, local administrative supervisory organs at all levels only accept the leadership of the supervisory organs at higher levels, and do not accept the leadership of the people's government at the corresponding level. Only in this way can the supervisory organ be ensured to have a higher legal status and greater authority, and to better perform its supervisory duties. Only in this way can the supervisory organs at all levels be guaranteed to exercise their functions and powers independently according to law, and 360 - degree full coverage and all-round supervision of all state public officials exercising public power can be achieved.

2) To strengthen the internal supervision and management mechanism: A supervision department should be set up within the supervision Committee to conduct routine supervision of its daily supervision, investigation 
and disposal activities, so that the investigation activities, investigation procedures and procedures of searching, sealing up and seizing of the supervision Committee can be monitored, supervised and managed, and the supervision activities can be carried out correctly according to law. In addition, the supervisory Committee should supervise between the upper and lower levels, and the upper level should guide the work of the lower level in a timely manner and correct the wrong behaviors of the lower level in a timely manner.

3) Improve the external supervision and restriction mechanism: The supervisory Committee shall accept the leadership of the party in the supervision work, and the major work arrangements and major issues involved in the investigation of duty crimes shall be reported to the party Committee in a timely manner. Accept the supervision of the people's congress, and the supervision of procuratorial organs on the investigation process of duty crimes and accept the supervision of the broad masses of the people. In addition, we should also give full play to the supervisory role of news media, so as to promote the development of supervisory supervision, and play a role in warning and education for serving officials, and constantly improve people's sense of ownership and enthusiasm for anticorruption and honesty.

\section{REFERENCES}

[1] Ouyang qingfang. research on discipline inspection and supervision from the perspective of national governance [M]. Hubei: central China normal university press, $2016.17-18$.

[2] Wu Jianxiong. study on improving the organizational structure of national supervision [J]. journal of Xiangtan university, 2017 ( 1 ).

[3] Ma Huaide. the significance and main task of the reform of national supervision system [J]. journal of China national school of administration, 2016 ( 6 ).

[4] The general office of the central Committee of the communist party of China issued the pilot scheme on the reform of national supervision system in Beijing, Shanxi and Zhejiang provinces

[5] Li middle east. research on system construction in China's current anti-corruption system. China ocean university. 2012.

[6] Si Lijuan. research on the changes of China's administrative supervision system since the reform and opening up. central China normal university. 2014.

[7] Zhang Xiaoyan. on improving the scientific nature of anti-corruption system. China's supervision. 2009.

[8] Xia yunjiao. research on administrative supervision. administration and law. 2005.

[9] Yuan Gang. research on eu Ombudsman system [M]. China university of political science and law press .2013

[10] ( British ) bradley. constitution and administrative law [M]. comercial press. 2008. 